\title{
Recurrences of transient synovitis of the hip
}

\author{
C M ILLINGWORTH
}

The Children's Hospital, Sheffield

SUMMARY Thirty six children with transient synovitis of the hip had a total of 80 recurrences, 69 of them personally observed, and 11 described by the mother. No features distinguished the initial attack of those who had a recurrence from that of the 18 children who have not so far had a recurrence. We analysed the total of 126 episodes. In 72 there was evidence of an associated infection from the history, clinical signs, and a raised antistreptolysin $O$ titre or isolation of a pathogen from a throat swab. The prognosis is difficult to assess because the symptoms, signs, and special investigations are not specific. Recurrences can occur after many years without symptoms.

Many children are taken to a doctor because of the recent onset of a limp or limb pains and in a 9 month period in 1976,123 of these children were brought to the accident and emergency department of this Hospital. ${ }^{1}$ None of them had signs of trauma, local sepsis, hemiplegia, or any other obvious cause and 76 were thought to have transient synovitis of the hip. Over 10 years 257 children were admitted to the Royal Liverpool Children's Hospital for this condition. ${ }^{2}$ Although transient synovitis of the hip is common, the Index Medicus for the past $11 \frac{1}{2}$ years (up to July 1982) listed less than a dozen published reports on the subject. It is a difficult condition to study because of the absence of specific symptoms or signs, the absence of specific findings on special investigation (except sometimes on radiographic examination), and the need for follow up over many years. As Sharrard wrote, ${ }^{3}$ the diagnosis is inevitably speculative and retrospective.

Transient synovitis of the hip occurs in children aged about 18 months to 12 years, particularly in those aged 5 to 6 years and in boys, and it often follows a respiratory tract infection. Diagnosis is based on a history of onset of a limp, refusal to bear weight on a leg, or pain on movement in the knee, thigh, or hip, together with limitation of abduction and internal rotation of the hip. The symptoms may last up to 14 or 21 days. The onset may be acute and severe so that a child who is well on going to bed is unable to walk or to bear weight on the leg in the morning. It is impossible to distinguish it clinically from Perthes's disease. The causative factors commonly mentioned are infection, trauma, and allergy, and Spock ${ }^{4}$ added obesity.

Few published reports mention recurrences: Rosenberg $^{5}$ found that of 36 children none had a recurrence; Spock $^{4}$ wrote that some children had a recurrent attack and 45 children $(17.4 \%)$ described in 4 published reports suffered a recurrence..$^{6-9}$ I was unable to find any study of recurrences of transient synovitis of the hip and because we were seeing many I collected records of 36 children who had subsequent attacks and include details of 18 other patients who have not so far had a recurrence.

\section{Method}

All 54 children ( 44 boys, 10 girls) seen between 1977 and mid 1982 (with 2 exceptions), satisfied the criteria described above. All had hip pain or limited movement and in many there was referred pain in the knee. All had radiographic examination of the hips to exclude Perthes's disease. Children found to have Perthes's disease at the first or subsequent examination were excluded. All had an erythrocyte sedimentation rate (ESR), white cell count, and throat swab and most had an antistreptolysin $\mathrm{O}$ (ASO) titre and test for $\mathrm{C}$ reactive protein. Where there was a possibility of rheumatoid arthritis we investigated for the rheumatoid factor by the latex method. Various studies by throat and stool culture were carried out on 33 children and a monospot test for infectious mononucleosis was done in 4 children. The mean age of the first attack in the 54 children was 6 years and 5 months and the distribution is set out in the table.

\section{Results}

Aetiology. In 52 episodes $(42 \%)$ the child had an upper respiratory tract infection when seen or within the previous 2 weeks. In a further 20 episodes $(16 \%)$ there was evidence of infection in a high ASO titre alone (8 episodes), a positive throat swab 
Table Age distribution of first attack of synovitis of the hip in 54 children

\begin{tabular}{cc}
\hline $\begin{array}{l}\text { Age } \\
\text { (years) }\end{array}$ & Number (\%) \\
\hline $2-3$ & $6(11)$ \\
$4-5$ & $18(33)$ \\
$6-7$ & $13(24)$ \\
$8-9$ & $10(19)$ \\
$10-12$ & $7(14)$ \\
\hline
\end{tabular}

for $\beta$ haemolytic streptococci alone (7 episodes), or a positive throat swab with a raised ASO titre (5 episodes). Three children had herpes labialis ( 2 of them included in the above, the third without an upper respiratory tract infection).

From 4 children a $\beta$ haemolytic streptococcus (Lancefield group C) was cultured (from 1 of these it was also cultured in a recurrent attack). These children were aged $6,8,9$, and 11 years, all had an ESR under $10 \mathrm{~mm} /$ hour, 1 had an ASO titre of 600 , and another had a titre of 1200 . From 2 children a $\beta$ haemolytic streptococcus (Lancefield Group G) was cultured; both had a normal ESR, the ASO titre was 600 in one and 1200 in the other, who also had diarrhoea.

Six of the 54 children had mild diarrhoea or vomiting at the time of the attack but none had a markedly raised temperature. All except 3 were otherwise well in the first and subsequent attacks. The incidence of infection was the same in first attacks and recurrences. Virological studies in all 11 patients investigated, tests for infectious mononucleosis in 4 children, and tests for $\mathrm{C}$ reactive protein in 31 children were all negative. The ESR was $<10 \mathrm{~mm} /$ hour in $68 \%,<15 \mathrm{~mm} /$ hour in $78 \%$, $16-20 \mathrm{~mm} /$ hour in $8 \%$, and $>21 \mathrm{~mm} /$ hour in $14 \%$. The white cell count was under $15000 / \mu l(15 \times$ $109 / 1)$ in $23 \%$ and $>15000 \mu l$ in 1 child. No information of value was provided by the white blood count or differential count.

Of the 30 children tested for rheumatoid factor and the antinuclear factor, 2 had a positive rheumatoid factor but were negative at follow up. The antinuclear factor was positive in a further 2. Two children had asthma or eczema. In 1 child there was patchy psoriasis with a family history of psoriasis, and in another child the father had psoriasis. It was difficult to assess the importance of trauma in this age group, especially in boys in whom vigorous pursuits are usual, but trauma may have been a factor in 3 patients.

All children had a radiographic examination of the hips on their first attendance at hospital and this was also done later if there had been doubt at the first examination. Twelve children were thought to have an abnormality-increased joint space, 'stand off', or effusion-and in 16 more an abnormality was suspected initially but later radiological findings were normal. To minimise pelvic irradiation in children who had had earlier episodis, only a throat swab and ASO titre were done and the children were reassessed after 48 hours' complete rest.

\section{Recurrences}

The 54 children had a total of 134 episodes of synovitis of the hip: 36 children had a total of 80 recurrences after the first attack, but only 69 were personally observed and analysed by me and the other 11 diagnoses depended on the mother's history. This must not be interpreted as the recurrence rate as my interest in recurrences developed over several years when I realised how frequent they were. The staff of the department now ask me to see all children who present with unexplained lin:p or failure to bear weight.

A further difficulty in assessing the recurrence rate is the need for a prolonged period of follow up-1 child had almost 7 years and another $5 \frac{1}{2}$ years between recurrences and 1 child had recurrences over a period of 10 years. Comparing the 36 children who have so far had a recurrence with 18 who have not, and with the 76 children previously described by me, ${ }^{1}$ it was impossible to pick out any features that indicated that a recurrence was likely. There were no apparent differences in these children.

Recurrences were particularly common within 6 months of the first attack $(43 \%$ of 70$) ; 29 \%$ of children had their first recurrence 7 to 12 months after the first attack, $13 \%$ in the second year, and $15 \%$ later still. One child had a total of 16 episodes of which 6 were seen by me. In almost half of the children with a recurrence the same hip was affected and in 7 children other joints as well as the hip were affected (mostly with pains only and without other physical signs).

\section{Discussion}

Limping children present a frequent diagnostic problem to accident and emergency departments and family doctors. When there is no helpful history of trauma common causes such as local infection with tender enlarged inguinal lymph nodes or local heat or tenderness somewhere in the lower limb are sought; it is necessary to determine whether the pain arises from the soft tissues, muscle, bones, or joints and the spine is examined for possible psoas spasm. When the only finding is limitation of movement of the hip joint or perhaps merely pain on moving it, especially in abduction or internal 
Skirrow's medium was streaked directly with a loopful of faeces and incubated at $42^{\circ} \mathrm{C}$. In addition, all 3 media were seeded with $0.2 \mathrm{ml}$ each of a filtrate prepared as described ${ }^{311} 12$ and incubated at $37^{\circ} \mathrm{C}$. All media were incubated in an atmosphere of $10 \% \mathrm{CO}_{2}, 18 \% \mathrm{O}_{2}$, and $72 \% \mathrm{~N}_{2}{ }^{3}$ for 48 hours. Colonies morphologically resembling $C$ jejuni were picked, subcultured, and identified according to Holdeman et al. ${ }^{13}$ Thermoresistance, sensitivity to nalidixic acid, hippurate hydrolysis, ${ }^{14}$ and $\mathrm{H}_{2} \mathrm{~S}$ production $^{15}$ were used for identification and biotyping of isolates.

Conventional techniques were used for the isolation and identification (including serotyping) of salmonellas and shigellas. Five Escherichia coli colonies per sample of faeces were tested for antigens associated with enteropathogenicity (EPEC) by using commercially available EPEC antisera (Hoechst, Behring-Werke, Germany; Wellcome Research Reagents, England), for enteroinvasiveness by Sereny's test (EIEC), and for both heat stabile and heat labile enterotoxin strains (ETEC) as described by Robins-Browne et al. ${ }^{16}$

\section{Results}

Recovery of bacterial pathogens from stool specimens. $C$ jejuni was isolated from $31 \%$ of children with diarrhoea regardless of their age group (Table 1) and in $19 \%$ of the controls. It was the sole pathogen in $15 \%$ and $14 \%$ respectively in the diarrhoea and control groups. The 13 isolates available for biotyping with hydrolysed hippurate belonged, with 1 exception, to biotype 1 .

The incidence of salmonellas and shigellas was $4 \%$ or less in all groups. EPEC strains were recovered from $43 \%$ of children with diarrhoea and from $23 \%$ of controls $(P<0 \cdot 01)$. ETEC strains of $E$ coli were detected in 12 patients with diarrhoea and 5 controls. No EIEC were found.

Age specific faecal excretion of $\boldsymbol{C}$. jejuni. There was a statistically significant difference $(P<0.01)$ between the isolation rate of $C$ jejuni from infants with diarrhoea and from controls up to age 8 months (Table 2). This was also true when children excreting $C$ jejuni as the sole bacterial pathogen were considered $(\mathrm{P}<0.02)$. This trend changed conspicuously once children reached the age of 9 months, and between 1 and 2 years of age there was a steady decline in number of children with $C$ jejuni associated diarrhoea. In contrast, in the control group the incidence of $C$ jejuni in the faeces increased markedly after 9 months of age. The finding of fewer cases of $C$ jejuni associated diarrhoea after age 1 year coincides with a general decline in the number of patients in this age group admitted to hospital with diarrhoea.

Table 1 Faecal excretion of Campylobacter jejuni and other bacterial pathogens in Sowetan children

\begin{tabular}{|c|c|c|c|c|c|c|}
\hline Group & $\begin{array}{l}\text { Age } \\
\text { (Months) }\end{array}$ & No & $\begin{array}{l}\text { C jejunias } \\
\text { sole bacterial } \\
\text { pathogens }\end{array}$ & $\begin{array}{l}\text { C jejuni plus } \\
\text { other bacterial } \\
\text { pathogens* }\end{array}$ & $\begin{array}{l}\text { Bacterial pathogens } \\
\text { other than } \\
\text { C jejuni* }\end{array}$ & $\begin{array}{l}\text { No bacterial } \\
\text { pathogens }\end{array}$ \\
\hline \multirow[t]{2}{*}{ Diarrhoea } & $\begin{array}{l}0-8 \\
9-24\end{array}$ & $\begin{array}{l}60 \\
51\end{array}$ & $\begin{array}{r}10 \\
7\end{array}$ & $\begin{array}{l}8 \\
9\end{array}$ & $\begin{array}{l}21 \\
11\end{array}$ & $\begin{array}{l}21 \\
24\end{array}$ \\
\hline & Total & 111 & 17 & 17 & 32 & 45 \\
\hline \multirow[t]{2}{*}{ Controls } & $\begin{array}{l}0-8 \\
9-24\end{array}$ & $\begin{array}{l}60 \\
51\end{array}$ & $\begin{array}{r}1 \\
14\end{array}$ & $\begin{array}{l}3 \\
3\end{array}$ & $\begin{array}{r}16 \\
2\end{array}$ & $\begin{array}{l}40 \\
28\end{array}$ \\
\hline & Total & 111 & 15 & 6 & 18 & 68 \\
\hline
\end{tabular}

*Mainly enteropathogenic Escherichia coli; some children harboured 2 or more pathogens.

Table 2 Age specific faecal excretion of Campylobacter jejuni

\begin{tabular}{|c|c|c|c|c|c|c|}
\hline Age group (months) & $<4$ & $5-8$ & $9-12$ & $13-16$ & $17-20$ & $21-24$ \\
\hline No investigated* & $2 \times 24$ & $2 \times 36$ & $2 \times 20$ & $2 \times 12$ & $2 \times 14$ & $2 \times 5$ \\
\hline $\begin{array}{l}\text { Total } C \text { jejuni isolations } \\
\text { Diarrhoeal patients, No (\%) } \\
\text { Controls, No (\%) }\end{array}$ & $\begin{array}{l}9(38) \\
3(13)\end{array}$ & $\begin{array}{l}9 \text { (25) } \\
1 \text { (3) }\end{array}$ & $\begin{array}{l}8(40) \\
7(35)\end{array}$ & $\begin{array}{l}2(17) \\
7(33)\end{array}$ & $\begin{array}{l}5(36) \\
4(29)\end{array}$ & $\begin{array}{l}1(20) \\
2(40)\end{array}$ \\
\hline $\begin{array}{l}\text { C jejuni as sole pathogen } \\
\text { Diarrhoeal patients, No (\%) } \\
\text { Controls, No (\%) }\end{array}$ & $\begin{array}{ll}6 & (25) \\
0 & (0)\end{array}$ & $\begin{array}{l}4(11) \\
1(3)\end{array}$ & $\begin{array}{l}5(25) \\
6(30)\end{array}$ & $\begin{array}{ll}1 & (8) \\
3 & (25)\end{array}$ & $\begin{array}{ll}1 & (7) \\
3 & (21)\end{array}$ & $\begin{array}{l}0(0) \\
2(40)\end{array}$ \\
\hline
\end{tabular}

*The diarrhoea and control groups were equally matched and the numbers are expressed as $2 \times$ the number of each of the respective matched groups. 


\section{References}

1 Illingworth CM. 123 limping children with no fracture, sprain, or obvious cause. Clin Pediatr (Phila) 1978; 17: $139-42$.

2 Hardinge $\mathrm{K}$. The etiology of transient synovitis of the hip in childhood. J Bone Joint Surg $[B r] 1970 ; 52: 100-7$.

3 Sharrard WJW. Paediatric orthopaedics and fractures. Oxford: Blackwell, 1979: 1409.

4 Spock A. Transient synovitis of the hip joint in children. Pediatrics 1959; 24: 1042-9.

5 Rosenberg NS, Smith EE. Transient synovitis of the hip. JPediatr 1956; 48: 776-81.

- Sharwood PF. The irritable hip syndrome in children. A long term follow up. Acta Orthop Scand 1981 ; 52: 633-8.

7 Jacobs BW. Synovitis of the hip in children and its significance. Pediatrics 1971 ; 47 : 558-66.

8 Adams JA. Transient synovitis of the hip joint in children. J Bone Joint Surg [Br] 1963; 45: 471-6.

9 Caravias DE. The significance of the so called 'irritable hips' in children. Arch Dis Child 1956; 31 : 415-8.

10 Wynne-Davies R, Gormley J. The aetiology of Perthes' disease. J Bone Joint Surg [Br] 1978; 60: 6-14.

11 Catterall A, Lloyd Roberts GC, Wynne-Davies R. Association of Perthes' disease with congenital anomalies of genito-urinary tract and inguinal region. Lancet 1971; i: 996-7.

12 Illingworth RS. Common symptoms of disease in children. Oxford: Blackwell, 1982: 239-50.

13 Chung S. Diseases of the developing hip joint. Pediatr Clin North Am 1977; 24 : 857-70.

14 Vidigal EC, Da Silva OL. Observation hip. Acta Orthop Scand 1981; 52: 191-5.

15 Blockey NJ, Gibson AAM, Goel KM. Monoarticular juvenile rheumatoid arthritis. J Bone Joint Surg [Br] 1980; 62: 368-71.
16 Ansell BM. Spondyloarthropathy in childhood; a review. $J R$ Soc Med 1981; 74: 205-9.

17 Valderrama JAF. The 'observation hip' syndrome and its late sequelae. J Bone Joint Surg [Br] 1963; 45: 462-70.

18 Donaldson WF. Transient synovitis of the hip joint. Pediatr Clin North Am 1955; 10: 1073-80.

19 Duma RJ, Weinberg AN, Medrek TF, Kunz LV. Streptococcal infections. Medicine (Baltimore) 1969; 48: 87-127.

20 Drusin LM, Ribble JC, Topf B. Group C streptococcal colonisation in a newborn nursery. Am J Dis Child 1973; 125: 820-1.

${ }^{21}$ Stewardson-Krieger P, Gotoff SP. Neonatal meningitis due to group $\mathbf{C}$ beta hemolytic streptococcus. $J$ Pediatr $1972 ; 90: 103-4$.

22 Benjamin JT, Perriello VA, Jr. Pharyngitis due to group C hemolytic streptococci in children. J Pediatr 1976; 89: 254-6.

23 Rom S. Letter: Beta hemolytic group C streptococcal respiratory infection in infant and horse. $J$ Pediatr 1977; $91: 845$.

24 Goldmann DA, Breton SJ. Group C streptococcal surgical wound infections transmitted by an anorectal and nasal carrier. Pediatrics 1978; 61: 235-7.

25 Adebonojo FO. Monoarticular arthritis; an unusual manifestation of infectious mononucleosis. Clin Pediatr (Phila) 1972; 11: 549-50.

Correspondence to Dr Cynthia Illingworth, Paediatric Accident and Emergency Department, Children's Hospital, Western Bank, Sheffield S10 2TH.

Received 3 March 1983 